\title{
VERTICAL RESTRAINTS: TAMING THE COMPETITION DISORDER
}

\author{
By Harshita Bhatnagar * E Vinay Mishra*
}

\section{Introduction}

\begin{abstract}
'People of the same trade seldom meet together, even for merriment and diversion, but the conversation ends in a conspiracy against the public, or in some contrivance to raise prices. It is impossible, indeed, to prevent such meetings, by any law which either could be executed, or would be consistent with liberty and justice.'

- Adam Smith
\end{abstract}

What Adam Smith envisaged decades ago is undisputedly the founding jurisprudence of the antitrust law all over the world today. Competition is not defined in law; however, it is generally understood to mean the process of rivalry to attract more customers, enhance profit or both in the hunger of dictating market dynamics. Evenhanded competition is a distant dream, and market-distortionary practices and anti-competitive forces may yet restrict the working of healthy competition in the economy. Also, the era of economic reforms has unleashed ever increasing competitive forces through liberalisation and globalisation. In the absence of adequate safeguards, enterprises may undermine the market by resorting to unfair practices for their short term gains. Restrictive business practices are among the many kinds of practice which the law regulates or prohibits in the public interest to ensure free and fair competition. Anti-competitive agreements as a restrictive business practice occupy the darkest corners of Indian business tactics, and are one of the foremost concerns of the Indian competition law. These agreements primarily aim to restrict competition and include inter alia cartelisation, predatory pricing, tie-in sales, re-sale price maintenance, abuse of dominance.

* Final year BA LLB (Honours), Gujarat National Law University, India.

** Final year BA LLB (Honours), Gujarat National Law University, India. 
India's Competition Act, 2002, deals with anti-competitive agreements in section $3,{ }^{1}$ dividing them into horizontal and vertical agreements. Horizontal agreements are those between enterprises at the same stage of the production chain, such as between two rivals; these are dealt with under a presumptive rule that appreciable adverse effect on competition is presumed. Vertical agreements are those between enterprises at different stages of the production chain, such as between manufacturer and distributor. These are dealt with on a rule of reason basis, ie appreciable adverse effect on competition needs to be proved by the Competition Commission of India, which essentially means that the positive as well as negative impact of such agreement on competition will have to be taken into account before coming to any conclusion. These concepts will be discussed at length in the later sections of this article.

The focus of this article is on vertical agreements and the resultant market distortions. The following segments of the paper will deal with the legislative history of the infant competition law in India, and will analyse the impressions of the vertical restraints in the Indian competition fabric with reference to the Competition Act, 2002 (yet to be enforced), Monopolies and Restrictive Trade Practices Act, 1969 (MRTP), and the Indian and international case laws. The article also touches on the issues of enforcement and the treating of the consequential developmental disorders in the economy.

\section{$2 \quad$ Legislative backdrop and current legal framework}

Vertical agreements under the Competition Act, 2002 are categorised as anti-competitive in spirit, contingent upon the adverse impact they have on the market dynamics. They are in the nature of restrictive trade practices as envisaged under the erstwhile MRTP. Such trade practices originally attracted the attention of several high level commissions, the reports of which proved quintessential in framing the effective regulative law regarding vertical restraints in India.

1 In the US, anti-competitive agreements are dealt with in the Sherman Act sec 1. In the UK, anti-competitive agreement is covered in Chapter I section 2 . In the EU, these are controlled by the re-numbered Article 81 of the Treaty of Rome. In Australia, anti-competitive agreements are covered in Part IV of the Trade Practices Act, 1974. In Canada, Part VI sec 45 covers anti-competitive agreements. 


\subsection{Monopolies Inquiry Commission Report, 1964}

In the context of vertical agreements, the Commission noted that practices restrictive of competition include the insistence of many manufacturers that their goods must not be sold below the price dictated by them. This is usually described as re-sale price maintenance. Even more widespread were the practices of exclusive dealing and tie-ups. ${ }^{2}$ The Commission's report was the first insight into the restrictive trade practices prevalent in India during and before the 1960's.

\subsection{Monopolies \& Restrictive Trade Practices Act, 1969}

The Act came into existence after the Commission's report. The relevant provisions of the Act relating to the restrictive trade practices covering vertical agreements include section 2(0) which defines a restrictive trade practice (RTP) as a trade practice which has, or may have, the effect of preventing, distorting or restricting competition in any manner. Section 33 deals with agreements relating to any of the trade practices as enumerated in sub-section (1) of the section, though restrictive in nature and therefore compulsorily registrable as per section $35 .^{3}$ Any given vertical agreement will not be per se void or illegal as per the sections. ${ }^{4}$ The decision whether the trade practice flowing from any such agreement is prejudicial to public interest or not can be made only by the Commission, and that too after an inquiry as prescribed under section 37 read with section 10(a) of the Act. Surprisingly, the Commission has held that subclauses (i) and (ii) in section 2(0) are RTPs themselves, without being required to be judged on the touchstone of competition. ${ }^{5}$

\subsection{Sanchar Committee Report, 1978}

The Committee suggested that bilateral agreements (vertical agreements) relating to the trade practices of minimum resale price maintenance, price discrimination, tie up sales, exclusive dealings, production sharing, conditional know-how and residuary agreements should be prohibited. The Committee further recommended that

2 SM Dugar Commentary on MRTP law, competition law and consumer protection law (4th edition) (2006).

Section 33: Registrable agreements relating to restrictive trade practices. Mahendra \& Mahendra Ltd $v$ Union of India (1974) 49 Com Cases 419 (SC). The Supreme Court held that a trade practice does not become a RTP merely because it falls within one or the other clause of section 33(1), but that it must also satisfy the definition of RTP contained in section 2(0).

5 'Standard Motor Products of India Ltd.' RTP Enquiry No. 98/ 1986, 13 April 1991. 
compulsory registration should be prohibited on the lines of competition legislation in Australia, Canada and New Zealand. ${ }^{6}$

\subsection{Consumer Protection (Amendment) Act, 1993}

The Consumer Protection Act, as originally framed, did not cover complaints against RTPs. This Act has however extended the jurisdiction covering the RTP relating to the tie-in sales (section $2(\mathrm{nn})$ of the Act). ${ }^{7}$ Thus, insofar as the tie-in sales are concerned, there is concurrent jurisdiction between the Competition Commission and the Consumer Disputes Redressal Authorities set up under the Act.

\subsection{Raghavan Committee Report, 2002}

This was a high level committee set by the government of India on Competition Policy and Law. It made recommendations regarding restrictive agreements stated to be anti-competitive agreements. It explained the agreements between enterprises by distinguishing between them as vertical and horizontal agreements, specifically mentioning these terms for the first time. Continuing with the earlier definition though, the report stated that vertical agreements are to be treated more leniently than the horizontal agreements as they are less pernicious. ${ }^{8}$ The report stated that the vertical restraints on competition include tie-in arrangements, exclusive supply agreements, exclusive distribution agreements, refusal to deal and re-sale price maintenance (RPM). The report of this committee is said to lay down the framework for the current competition law in the India.

\subsection{Competition Act, 2002 (yet to be enforced, thus MRTP is still followed even though it has been repealed)}

This Act repealed the provisions of the MRTP. Moreover, in the era of liberalisation, privatisation and globalisation, it was felt that the existing MRTP had become obsolete in certain respects and that there was a need to shift the focus from curbing monopolies to promoting competition. The new competition law provides for a modern framework of competition. Section 3 has been enacted by the Competition Act, 2002 to tackle anti-competitive agreements. The Act declares void any agreement by an enterprise or association of

6 Dugar (n 2 above) 660.

7 Sec $2(\mathrm{nn})$ states that: "restrictive trade practice means any trade practice which requires a consumer to buy, hire or avail of any goods or, as the case may be, services as a condition precedent for buying, hiring or availing of other goods or services'.

8 Dugar (n 2 above) 684, 686. This change in attitude was drawn from the US example, where in recent times, under the rule of reason, vertical agreements are treated more leniently as they can often perform pro competitive functions. 
enterprises which restricts the production, supply, distribution, acquisition or control of goods or provision of services. The Act recognises horizontal and vertical agreements as having the potential to restrict competition in an economy. ${ }^{9}$ Our detailed analysis of the vertical agreements will now begin in the light of the present competition law in our country.

\section{$3 \quad$ Vertical restraints: Impressions on competition}

Vertical agreements are mostly the result of complex business negotiations. Agreements can therefore not be pushed into straightjacket schemes, since every agreement differs from one another as business relationships do. Therefore, for competition law purposes, classifications take place in form of 'components' of vertical restraints. In practice, many vertical agreements make use of more than one of these components. To give an example, exclusive distribution usually limits the number of buyers the suppliers can sell to while at the same time limiting the area where the buyers can be active. The first component may lead to foreclosure of other buyers, while the second component may lead to price discrimination.

\subsection{A different school of thought}

In the academic debate, the position had swung from regarding vertical restraints as suspect for competition, to a generalised perception that they were innocuous for competition by the early 1980 's. An argument in favour of this change was that economists were more cautious in their assessment of vertical agreements and less willing to make sweeping generalisations. ${ }^{10}$ Generally in economic theory two main schools of thought can be distinguished when dealing with vertical restraints.

\subsubsection{The Chicago school}

The Chicago School has used neoclassical insights to argue in general that only a limited number of cases concern antitrust law. Chicago School researchers asserted that antitrust law should mainly address horizontal arrangements and practices. For vertical arrangements, the Chicago School argued that the occurrence of allegedly anti-

$9 \quad$ The Competition Act sec 3(1).

10 'The Economics of Verticals' Competition Policy Newsletter 1998 http:// europa.eu.int/comm/competition/speeches/text/sp1998_020_en.htm> (accessed 8 September 2008). 
competitive practices spells no efficiency loss and may in fact even be pro-competitive. ${ }^{11}$

Vertical restraints are agreements between producers of 'complementary' goods or services rather than competing suppliers of substitutes. Suppliers of such goods or services have no interest in raising the price of a complementary product because by definition it will decrease the demand for its own product. This reasoning can also be related to the well-known discussion on inter-brand versus intrabrand competition. From a Chicago-type perspective, a wellfunctioning inter-brand competition among producers can substitute intra-brand competition among retailers. Recent literature on vertical foreclosure challenges the Chicago School's friendly position on vertical restraints. ${ }^{12}$

Critical voices often find Chicago applications to be unrealistic, divorced from observations in actual markets, and tending to obscure the importance of dynamic considerations, asymmetric information, and strategic behaviour.

\subsubsection{Modern European economics (post-Chicago scholars)}

This supposes that vertical restraints can be efficiency-enhancing since they can help to eliminate some form of vertical externality in the manufacturer-retailer relationship, as well as horizontal externality such as free-riding problems among retailers. However, the European School does not follow the findings of the Chicago School. According to the European School, some of the vertical restraints can be anti-competitive since they may serve to eliminate competition either at the manufacture level or at the retail level, and reduce consumers' choice and welfare. Which of these effects dominates and which vertical restraints will be adopted in a particular situation depend critically on the informational environment. ${ }^{13}$ More recently, work done by Kerber and Vezzoso advocates the utilisation of an analysis as to what extent evolutionary theories of competition

D Hildebrand 'Economic analysis of vertical agreements' (2005) 17 International Competition Law Series 10. For example, Chicago School scholars have argued that resale price maintenance is likely to be pro-competitive unless it serves to facilitate a horizontal cartel. Otherwise, a rational manufacturer would only engage in this practice to induce retailers to provide consumers valuable but costly services that they would not otherwise provide. As a result of the impact of the Chicago School, the courts rarely consider non-price restraints illegal and the enforcement agencies in the US almost never challenge vertical restraints, even when price-related.

12 Dugar (n 2 above) 11; Tor 'Developing a behavioral approach to antitrust law and economics' http://www.luc.edu/law/academics/special/center/antitrust/tors umry.pdf (accessed 7 September 2008). Some scholars have been applying recent economic insights to challenge the simplistic microeconomic learning of the Chicago School, even while retaining its fundamental economic commitment to efficiency concerns.

13 Hildebrand (n 11 above) 12. 
and innovation economics can be used to derive additional new criteria for the assessment of vertical restraints. Specific evolutionary arguments such as subjective and local knowledge, the heterogeneity of knowledge bases of firms, communication and learning problems, and the complementarity of knowledge (systematic innovations) could be used for deriving additional new assessment criteria for vertical restraints. ${ }^{14}$

\section{$4 \quad$ Types of vertical restraints}

These agreements as identified in section 3(4) under the following headings:

- Tie-in arrangement;

- Exclusive supply agreement;

- Refusal to deal;

- Re-sale price maintenance.

Such agreements shall be regarded as anti-competitive and in contravention of section 3(1) only when it is established that they fall under sub-section (4) and cause or are likely to cause an appreciable adverse effect on competition in India. ${ }^{15}$ The onus lies on the complainant to substantiate the allegations. ${ }^{16}$ It is first imperative to comprehend the depth and dimensions of the concept of appreciable adverse market effect as mentioned in section 3(4) vis-à-vis section $3(1)$.

\subsection{Causes or likely to cause adverse effect on competition: Sub-section (1)}

This expression unambiguously states that the agreement should affect the competition within India; such effect must be appreciable - not imperceivably minimal - and either affecting or expected to hinder free and fair competition. Thus, it is noteworthy that the only material factor for consideration here is the potential and impending threat to competition by virtue of the agreement, irrespective of the intention and the actual damage that has occurred to competition. ${ }^{17}$

Hildebrand (n 11 above) 13.

Competition Act sec 3(4).

Dugar (n 2 above) 688.

Summit Health $v$ Pinhas 500 US 322; United States $v$ Griffith 334 US 100. The Court observed that specific intent, in the sense in which the common law uses the terms, is necessary only where the act falls short of the results prohibited by the Sherman Act. 


\subsection{Appreciable adverse effect on competition: Sub-sections (1), (3), (4)}

The term 'appreciable' has not been defined in the Act. However, it has been defined in Law Lexicon as 'capable of being estimated, weighed, judged of, or recognised by the mind, capable of being perceived or recognised by the senses, perceptible but not a synonym of substantial.' In terms of section 19(3), the Commission shall have due regard to the various factors specified therein in clauses (a) to (f) while determining whether an agreement has an appreciable adverse effect on competition under section 3 . One must note that it is purely in the realm of estimation, and is subjective. An agreement falling under sub-section (4) in contravention of the provisions of sub-section (1) shall be void. ${ }^{18}$

Interestingly, despite the fact that the two categories of agreements are significantly different, the horizontal agreements under sub-section (3) being per se violative and vertical agreements under sub-section (4) are subjected to the rule of reason, both have been treated alike and declared void under sub-section (2). It is a moot point whether these agreements are void ab initio or become void after an order is passed by the Commission after enquiry under section 27. Lack of clarity in this regard is likely to cause needless litigation between the parties to the impugned agreement in-as-much as an agreement which is void is not enforceable in a court of law. ${ }^{19}$ Now we move on to discuss each of the above mentioned vertical restraints in detail.

\section{$5 \quad$ Vertical restraints vis-à-vis theory of economic efficiency: Facing the real challenge}

Vertical restraint law in antitrust has not been a very fertile area for commentary in the Indian competition arena. With the economic efficiency approach in antitrust gaining strength in the world economy, vertical restraint law appears to be all but dead. ${ }^{20}$ In India the economic efficiency approach ${ }^{21}$ has seeped in with the Competition Act, 2002 and MRTP, 1969, restricting those vertical agreements which have or are likely to have an adverse effect on competition. Today, world over, vertical restraints are considered benign, if not beneficial, for consumers. They assert that vertical restraints of any sort - whether territorial restrictions, bans on

18 Under the Indian Contracts Act, $1872 \mathrm{sec} 2(\mathrm{~g})$ states that an agreement not enforceable by law is said to be void.

19 Dugar (n 2 above).

20 JW Burns 'Vertical restraints, efficiency, and the real world' (1993) 62 Fordham Law Review 597.

21 As above. 
discounting, or tie-ins - give consumers more product-mixes from which to choose in the inter-brand market. ${ }^{22}$ Our very own Indian anti-trust jurisprudence is based primarily on the economic efficiency approach, and the Competition Act has a categorical systematic proconsumer approach. However, the time is ripe now to reconsider the long followed economic efficiency approach in India and the world, which Professor Jean W. Burns argues suffers from two fatal flaws. First, there is growing evidence that it is incomplete, in the sense of ignoring issues that society wants considered. Second, consumers are increasingly indicating that they simply do not believe the theory, as it is divorced from the real world. These two novel criticisms are summarily explained below.

\subsection{The incompleteness of the economic efficiency approach}

The economic efficiency approach has eliminated from the antitrust calculus all consideration of the concerns centring on the dealer's as separated from the consumer's wellbeing; the identical dealerfairness issues continue to surface in a variety of contexts and legal theories outside of antitrust. Whatever legal theory is invoked, the common denominator in these cases should be a detailed case-bycase, industry-by-industry inquiry into the fairness of the transaction, and the good faith and bargaining power of the parties. In doing so the courts should engage in the balancing of competing supplier and dealer concerns that antitrust courts, more often than not, shun. Jurisprudentially, then, the balancing of fairness versus economic concerns that previously took place within antitrust analysis is now taking place across the bounds of different legal theories. Put another way, these new dealer remedies are filling the very gap left in antitrust by the economic efficiency approach. These theories, inter alia, include breach of an implied covenant of good faith and fair dealing, ${ }^{23}$ tortious interference with contract, ${ }^{24}$ equitable estoppel, ${ }^{25}$ breach of an oral contract, ${ }^{26}$ and breach of fiduciary duty. 27

One of the principal changes brought about by the economic efficiency approach has been a recognition that vertical restraints may well have pro competitive effects in the inter brand market. JW Burns 'The Chicago school and the evolution of antitrust: Characterisation, antitrust injury, and evidentiary sufficiency' (1989) 75 Virginia Law Review 1221, 1231-37.

23 This theory is often used by courts in determining the intention of the parties when the contract is silent on a given point.

24 American Business Interiors, Inc. v Haworth, Inc., 798 F.2d 1135, 1142-46 (8th Cir. 1986); Machine Maintenance \& Equipment Co. v Cooper Industry, Inc. 661 F. Supp. 1112, 115-17 (E.D. Mo. 1987).

25 Chem-Tek, Inc. v General Motors Corp. 816 F. Supp. 123, 131 (D. Conn. 1993).

26 Lano Equip., Inc. v Clark Equip. Co. 399 N.W.2d 694 (Minn. Ct. App. 1987).

27 Domed Stadium Hotel, Inc. v Holiday Inns, Inc. 732 F.2d 480, 485 (5th Cir. 1984). Of the various common law theories, this one has probably been the least successful for dealers as most courts reject the notion that a supplier has a fiduciary duty toward its dealer. 


\subsection{Perceived lack of connection with the real world}

A second flaw in the economic efficiency approach is its perceived lack of connection with the real world, evidenced by the growing public criticism of the economic theory and vertical restraints in particular. Sophisticated consumer groups, the popular press, and elected officials are all increasingly indicating that, contrary to the economic theory, they regard dealer protection and intra-brand competition as vital for market efficiency and low prices. ${ }^{28}$ Rather than supporting the economic efficiency theory, which purports to be pro-consumer, consumer lobbies are working to undo its effects. 29 The consumer advocacy groups cite studies showing that vertical pricing restraints cost consumers over $\$ 1$ billion each year ${ }^{30}$ and raise prices by as much as fifty percent. ${ }^{31}$ To these consumer organisations, the true ally of the consumer is not the manufacturer, as the economic efficiency advocates argue, but the discounting dealer. ${ }^{32}$

Various popular press newspapers and magazines echo the same views. These papers and magazines, which are far more likely to reflect the views of the common consumer than the Journal of Law and Economics, characterise vertical restraints as a way in which manufacturers and retailers, 'hungry for fatter profits' 'rig' the marketplace. ${ }^{33}$ Hence, the economic efficiency argument in favour of vertical restraints is not a value-neutral theory, but rather is part of a politically pro-business bias. ${ }^{34}$

The above two propositions affect not only the current law of vertical restraints but also raise significant questions about the future of the new dealer remedies and antitrust jurisprudence. Thereby, the simplification of antitrust vertical restraint law brought about by

28

29 A spokesperson for Consumers Union, for instance, has written: 'Consumers who benefit from the $\$ 125$ billion discount industry ... should take note [of resale price maintenance] ... Legislation is pending in Congress that would restore some protection afforded to discounters and help turn back the judicial attack on price competition ... [I]f President Bush is at all concerned with the welfare of low and middle income consumers, he should sign the legislation.' MK Rand 'Fixing prices with a nod and a wink' Christian Science Monitor (24 April 1990) 19.

Consumers Union cites a 1969 Economic Report of the President showing that resale price maintenance costs consumers $\$ 1.2$ billion per year. Consumers Union 'Why consumers need H.R. 1470, the Price-Fixing Prevention Act of 1991' 1 (unpublished press release), criticising the Chicago School as an 'anti-consumer theory of economics'. House Judiciary Committee Chairman J Brooks has been quoted as saying that resale price maintenance costs consumers $\$ 20$ billion a year. P Barrett 'Anti-discount policies of manufacturers are penalising certain cut-price stores' Wall Street Journal (27 February 1991) B1.

31 Public Citizen's Congress Watch conducted a study that showed a difference of 10 to $45 \%$ when RPM was permitted. M Waldman \& JW Cuneo 'Business Forum: Doom For Discounters?' New York Times 15 May 1988 www.newyorktimes.com (accessed 8 September 2008).

32 Rand (n 29 above) 19.

33 Burns (n 20 above) 58

34 As above. 
economic theory is being proved illusory, especially in the US With the Competition Act (soon to be implemented) relying on the adverse effect on competition to gauge the impact of vertical restraints, India is likely to face the biggest challenge of balancing the fair dealership interests and consumer interests in the Indian competition dynamics.

\section{The horizontal-vertical dichotomy: The alternative analysis of agreements}

Determining whether a contract, combination, or conspiracy is horizontal or vertical can make or break a case under India's first canon of antitrust law. What the Indian anti-trust jurisprudence religiously follows to distinguish between the two kinds of agreements is what we call the 'source rule'.

\subsection{Source rule and the consequent obscurity}

Lately courts have trumpeted a single rule for determining whether a restraint is horizontal or vertical: A horizontal agreement occurs when competitors at the same market level agree to restrain trade, whether at their own or another market level, whereas vertical restraints result when persons or firms at different market levels in the chain of distribution of a specific product conspire to restrain trade. The rule as expressed focuses on the source of the restraint. We thus call it the source rule. ${ }^{35}$

Notwithstanding the importance of the horizontal/vertical determination to antitrust law, case law discussing in detail the line between horizontal and vertical is relatively sparse - though the issue may have been decided a number of times without specific detailed analysis in several of the cases.

Belying this scarcity, many common business arrangements would be difficult to classify as either horizontal or vertical under the source rule. As long as competitors participate in or own interests in entities which operate at all levels of distribution, focusing only on the source of the restraint will result in entities being both horizontal and vertical. The source rule therefore cannot be the sole test for whether a restraint is imposed vertically or horizontally. ${ }^{36}$ One such example is of the dual distribution cases as discussed below.

CR Loftis \& V Ricks 'Seeing the diagonal clearly: Telling vertical from horizontal in antitrust law’ (1996) 28 University of Toledo Law Review 151. As above. 


\subsection{Challenge posed by dual distribution cases}

Dual distribution cases are those in which an entity such as a manufacturer or supplier, with an otherwise clearly vertical relationship to its wholesalers or retailers, enters the wholesale or retail level of distribution and directly competes with those it also supplies. ${ }^{37}$ It is in these dual distribution cases where the verticality or horizontality of the manufacturer or supplier is directly at issue. ${ }^{38}$

Often the manufacturer will take up distribution of its product in one of the exclusive areas it has established in order to cut costs further. When the manufacturer thus also becomes a distributor, the other distributors or potential distributors of the manufacturer sometimes complain that, because the manufacturer operates at the same level as the distributors, the arrangement between the manufacturer and the other distributors is horizontal rather than vertical. $^{39}$

It is generally accepted that so long as the dual distribution arrangement promotes inter-brand competition by allowing the vertical entity to pursue its own market strategies by promoting certain efficiencies in the distribution of its product, the arrangement is held for all substantive purposes to be vertical. ${ }^{40}$ There is no case of which the researcher is aware of, where the Indian Supreme Court has discussed in detail and specificity the problems of dual distribution cases in relation to determining the border line between the vertical and horizontal restraints and, hence, this area requires analysis and substantive research both by Indian scholars and jurists at the earliest.

\subsection{Alternative approaches}

Though the researcher does not particularly support any of the alternative approaches for determination of vertical and horizontal agreements from the criteria given and followed by the Indian competition law today, it is still vital for the comprehensiveness of this research project to discuss these approaches in brief.

Professor Leibeler has called for the abandonment of the horizontal/vertical distinction in favour of an analysis based on intra-

H Hovenkamp 'Vertical restrictions and monopoly power' (1984) 64 Boston University Law Review 521, 546-48.

38 Oreck Corp. $v$ Whirlpool Corp. 579 F.2d 126, 131 (2d Cir. 1978). The Court held a dual distribution arrangement to be vertical in effect and purpose while employing rule of reason analysis.

39 As above.

40 Com-Tel, Inc. v DuKane Corp. 669 F.2d 404, 409-11 (6th Cir. 1982). The courts in the US have reasoned that dual distribution cases are actually vertical cases except for the sole fact that the manufacturer also participates on the lower distribution level. 
brand and inter-brand effects. Under this analysis, an arrangement that only affects intra-brand competition should be judged under the rule of reason regardless of whether it is the result of horizontal or vertical agreements. ${ }^{41}$ This distinction has been acknowledged by the Department of Justice in the United States of America. After reviewing traditional antitrust classifications of agreements, Professors Baxter and Kessler, Professors of Economics, Law, and Policy at the Graduate School of Business at Stanford University, concurred that these labels of agreements are unhelpful and misleading. The classification of an agreement as horizontal or vertical provides little guidance as to either its effect on social welfare or its legality under the antitrust laws. The authors propose an alternative system that classifies agreements based on the parties' economic relationships as producers of substitutes or of complements. They also suggest that an unwillingness to recognise that many agreements affect relationships with producers of both substitutes and complements has led to confusion in the antitrust analysis of agreements. In conclusion, they discuss the welfare analysis of such agreements and propose a method of evaluating their legality under the antitrust laws. ${ }^{42}$

\section{$7 \quad$ Model law for vertical arrangements: Do we need to follow the US/EU models?}

Even though the Indian competition law claims to be self-sufficient, we must examine the need (if any) for importing relevant jurisprudence/framework from the two strongholds of the world antitrust laws, namely the US and the EU frameworks. In recent years, divergence between United States and European Union's competition policy has garnered a lot of attention. One particular area where these differences are evident is the treatment of vertical restraints. The policies of these frameworks with reference to vertical restraints are analysed in brief below.

\subsection{The US model}

In the US, a plaintiff can challenge vertical restraints under section 1 of the Sherman Antitrust Act as an unreasonable restraint of trade, or under section 2 as exclusionary conduct in furtherance of monopoly power. Under either cause of action, a plaintiff must show that the agreement in question is likely to harm competition. US antitrust laws seek to maximise consumer welfare by controlling the misuse of

41 WJ Leibeler 'The antitrust paradox: A policy at war with itself' (1978) 66 California Law Review 1317.

42 W Baxter \& D Kessler 'Toward a consistent theory of the welfare analysis of agreements' (1995) 47 Stanford Law Review 615. 
private economic power. In other words, the US model, unlike its European counter-part as will be discussed, protects the competitive process - not competitors. ${ }^{43}$

Two cases which claim inevitable reference with regard to US antitrust jurisprudence are GTE Sylvania, Inc. ${ }^{44}$ where in support of its abandonment of per se treatment, the Supreme Court observed how exclusive territories had the potential to "induce competent and aggressive retailers to make the kind of investment of capital and labour that is often required in the distribution of products unknown to the consumer' A few years later, in Monsanto Co. v Spray-Rite Service Co., the Court again endorsed vertical restrictions that encourage retail service and supported a manufacturer's right to terminate a discounting dealer to prevent free riding. ${ }^{45}$

Vertical restraints can thus be broadly classified into two categories in the US. The first category consists of arrangements that restrict the distribution of a product, such as resale price maintenance systems. Because they have a high potential to result in pro-competitive benefits, courts have analysed these arrangements under a rule of reason approach, but only when there is no agreement to set prices. ${ }^{46}$ The second category of vertical restraints consists of efforts by a firm to exclude or foreclose competing firms. These are also analysed under a rule of reason approach.

\subsection{Problems with the US framework}

As examined above, the economic efficiency approach which the US antitrust law follows, and is imitated by India to a large extent, is recently under a magnifying glass and is being criticised as biased against the manufacturers. One must remember that the United States has a rich history of antitrust case laws on which its federal judiciary can rely in deciding the validity of business practices. However, antitrust policy in India is still maturing with time, and consequently any blind application of the US framework would lead to immense difficulty due to unfamiliarity of the Indian courts with the US business approaches and practices. Almost all the business practices in the United States are analysed under a rule of reason approach, as also followed by India. However, this approach encompasses a great deal of discretion by the judge or finder of fact which may not be ideal in an emerging economy as this uncertainty may deter foreign investors from investing in India at this stage when there is rampant desperation for growth and development.

43

MM Sheth 'Formulating antitrust policy in emerging economies' (1997) 86 Georgetown Law Journal 451.

44433 US 55.

45465 US 752, 760-61 (1984).

46 United States v Colgate \& Co 250 US 300, 307 (1919). 


\subsection{The European Community model}

In contrast to American law, EU competition law is far less forgiving of vertical agreements. The antitrust regime in the European Community is based on a dominance concept: any conduct that injures consumers or competitors is a violation of the antitrust laws because it is an abuse of a dominant position. ${ }^{47}$ The objective of EC antitrust law is to protect vulnerable competitors against abusive practices by dominant producers. ${ }^{48}$

The Commission can challenge vertical agreements entered into by both dominant and non-dominant firms under article 81 , and can challenge those entered into by dominant firms under article 82.49 The Commission's burden does not require an analysis of competitive effects of the sort undertaken in the US. Rather, EU case law suggests that it is enough for the Commission to show that the agreement in question restricted the economic freedom of either a party to the agreement or a third party, without regard to a likely effect on prices, output, or consumer welfare generally. ${ }^{50}$

The EC recently has promulgated a block exemption regulation (BER) that sets out circumstances under which vertical arrangements are automatically exempted under article 81(3). The BER makes great strides in applying economic rather than formalistic analysis to the antitrust treatment of vertical restraints, and explicitly recognises many of the efficiency-enhancing reasons for vertical restraints. ${ }^{51}$ Nevertheless, article 81 is still likely to subject a greater number of agreements to condemnation than would US antitrust law. For example, the exemption applies only to firms with less than 30 per cent market share; US courts typically use a higher market power threshold as a screen for rule of reason analysis. ${ }^{52}$ Further, the BER explicitly spells out several categories of so-called 'hard core' distribution restrictions that essentially are per se illegal. Dominant firms entering into vertical agreements receive even harsher treatment under EU competition law. The guidelines to the BER

AE Rodriguez \& MB Coate 'Limits to antitrust policy for reforming economies' (1996) 18 Houston Journal of International Law 311.

48 J Cooper et al 'A comparative study of United States and European Union approaches to vertical policy' (2005) 13 George Mason Law Review 289.

49 Treaty Establishing the European Community, 1997. As of 1 May 2004, national competition authorities and courts of EU member countries can fully apply both articles 81 and 82. See 'Commission Regulation 773/2004, 2003 O.J. (L 1) 37, 39 on implementations of the rules on competition laid down in articles 81 and 82 of the Treaty' http://europa.eu.int/comm/competition/publications/publications/ modernisationen.pdf (accessed 10 September 2008).

50 SB Bishop 'Pro-competitive exclusive supply agreements: How refreshing!' (2003) 24 European Competition Law Review 229.

51 'Commission Notice: Guidelines on vertical restraints' (2000) C291 Official Journal 115.

52 Jefferson Parish Hosp. Dist. No. 2 v Hyde, 466 US 2, 26-27 (1984). The Court observed that $30 \%$ market share was insufficient for market power in a tying case. 
explicitly exclude dominant firms from exemption under article $81(3) .^{53}$

The recent settlement between Coca-Cola and the EC that ended a five-year investigation of Coca-Cola's marketing practices in the EU illustrates EU hostility to restrictions on downstream distributors, regardless of the competitive effect. Although it is impossible to know what evidence the Commission had regarding the effects of CocaCola's agreements on consumer welfare, the Commission's press release strongly suggested that the competition issue involved was consumer ability to choose from competing brands rather than supracompetitive pricing of Coca-Cola's offerings. 54

\subsection{Problems with the EC framework}

The first problem in adopting the EC framework for an emerging economy like India is that it gives little, if any, consideration to efficiency justifications for violations of antitrust law. Rather, the focus of European competition law is the redistribution of wealth. Implementing such a policy in an emerging economy can entail significant lost opportunities for economic growth. The cost of foregone efficiency benefits not only affects present levels of economic growth and output, but future levels as well because firms are deterred from entering efficiency-enhancing agreements due to fear of violating the antitrust laws.

A second problem with the European framework is that it was specifically designed for a large market (in the hopes of producing a more competitive Community Economy). India is not a part of very large trading blocs or unified markets (though recently the trend is changing, with India joining hands with other developing countries and entering into free trade agreements). Rather, India has a host of bilateral trade agreements with various neighboring countries. Additionally, one of the foremost aims of the Indian economy is to try to attract foreign investment to increase economic growth. Thus, the aims of EC antitrust policy are inconsistent with the size, structure, and goals of Indian economy.

AKZO Chemie BV v Comm'n 1991 E.C.R I-3359, P 60 (1989); S Bishop \& D Ridyard 'E.C. vertical restraints guidelines: Effects based or per se policy" (2002) 23 European Competition Law Review 35. Dominance is established under EC law when a firm's market share is above 50 percent.

54 European Commission 'Commission close to settle antitrust probe into Coca Cola practices in Europe' 19 October 2004 http://europa.eu.int/rapid/ (accessed 10 September 2008). 
The economic, legal, and political structure of India is very different from those of the United States and the European Community. Though the bulk of Indian competition law is imported from US antitrust jurisprudence, much is left to be desired. Broadly, the three main goals of the Indian economy today include increasing economic growth with the promotion of $\mathrm{FDI}$; to increase access to and development of new technologies; and to increase efficiency of domestic firms. The competition policy in India regarding vertical restraints must, therefore, juggle between the consumer welfare standard and the aggregate economic welfare standard as the benchmark for analysing allegedly anticompetitive conduct of a given agreement.

Indian law at present is consumer-oriented. This will in future enhance healthy competition in the market. However, with the imminent arrival of Wallmart, India may face market distortions and may have to reconsider its stand on the vertical restraint law that is prevalent today. The courts now need to interpret the law not only in a consumer-friendly approach, but also give due credence to the dealer fairness attributes of any agreement to ensure full fledged, unhindered growth of the Indian economy in the twenty-first century. However, it is to be noted that any immediate changes or amendments to the competition law may not be required once the Competition Act is implemented; its results on the Indian competition scenario may eventually trigger the above-explained recourses.

\section{Conclusion}

As all successful competitive moves tend to exclude rivals, the ability to neatly distinguish between pro- and anti-competitive vertical restrictions is not easy in practice, and continues to be a central focus of antitrust scholarship all over the world today. From the above analysis it is amply clear that courts should reconsider their almost total reliance on the economic efficiency approach in analysing vertical restraints under the antitrust laws. We must understand that no theory, no matter how internally logical, consistent, or simplifying, will long survive if that theory is not believed and does not suit society's needs.

The law of vertical restraints is a good deal broader than we recognise it to be in India, and also includes a variety of common law 
theories. ${ }^{55}$ Though, as of today, we may let our Competition Act rest in peace as very soon the State legislatures and courts will require case-by-case inquiries into dealer fairness and general business ethics issues. This will in effect circumvent the simplicity and logic of the old antitrust learning from the US model.

While a detailed plan for the future of vertical restraints in antitrust law is beyond the scope of this article, some broad outlines are possible. The growing disbelief in the economic efficiency theory is a clear sign that courts need to rethink their almost total reliance on this theory and its models in anti-trust jurisprudence. Therefore, any adverse effect on the market must not solely be judged in accordance with a pro-consumer outlook. Tie-ins and non-price vertical restraints should be subjected to a fuller rule of reason analysis that includes consideration of intra-brand competition and dealer fairness. In short, the time has come to move away from theory and into the real world, and consider what goals society wants protected and how consumers regard their self interest as best served. 